\title{
WOMEN LEADERSHIP AND ITS ASSOCIATION TO INDIVIDUAL CHARACTERISTICS, SOCIAL SUPPORT, AND DIVERSITY OF WORK ENVIRONMENT
}

\author{
Eddy Madiono Sutanto* \\ Petra Christian University, Indonesia \\ Vilensya Aveline \\ Petra Christian University, Indonesia
}

\begin{abstract}
This research was conducted to see the association of women leadership and individual characteristic, social support, and the diversity of working environment on women leaders. It was conducted on one of the largest textiles listed company in Indonesia with a market capitalization of more than six trillion Rupiah. This type of research is quantitative associative explanation. Purposive sampling method was used to obtain a population that fits in the criteria of a leader who have position as supervisor above to be the respondents. 100 female leaders who have been working more than a year in the company were qualified as respondents. Questionnaires were used with closed and opened questions. In order to analyzed the association between variables, the data was analyzed by Chi-Square analysis using SPSS. The respondents were 100 women leaders of a listed textile manufacturing company in Indonesia. The result showed that women leaders, who had high leadership capabilities due to the individual characteristic fit as a leader. They received social supports, especially from their spouses. Moreover, high diversity of working environment helped their networking. There were two kinds of individual characteristic (age and marital status) had no associative with women leadership.
\end{abstract}

Keywords: Women Leadership, Individual Characteristic, Social Support, Diverse Working Environment.

Received: 28 January 2019

Accepted: 10 May 2021

https://doi.org/10.33736/ijbs.3760.2021

\section{INTRODUCTION}

Women still face challenges while participating in decision making. According to a research conducted by Grant Thornton International Business Report (IBR), the leadership of women in Indonesian companies has decreased from 41 percent in 2014 to 22 percent in 2015. This percentage puts Indonesia below the average, women's average global leadership of 22 percent and the average developing country in Asia Pacific 23 percent (Wulandari, 2015). The McKinsey\&Company survey institute $(2008,2012)$ reveals that the percentage of women leadership in Indonesia is declining in the middle management level, and is smaller in the level of directors. This shows the obstacles of women leaders to achieving peak leadership (Bullough et al., 2012).

\footnotetext{
- Corresponding author: Eddy Madiono Sutanto, School of Business Management, Petra Christian University, 60236, Surabaya, East Java, Indonesia. Tel: +62818391691. Email: esutanto@petra.ac.id
} 
The small percentage of women leader who occupy the top leadership seat, indicates the factors that influence the leadership of women in an organization, among others, individual characteristics, social support, and the diversity of work environments. This is in line with findings Jepson (2010) and Lahti (2013). According to a survey conducted by Talouselämä magazine to 128 women in top management positions, most have less confident characteristics to be the most influential factor for most women in Finland to move forward (Lahti, 2013).

In the social support factor, women in Ethiopia are often considered merely suitable for carrying out administrative work, rather than taking decisions, this is known as gender stereotype (Bullough, 2008). Other research shows women in Jordan cannot develop a career without any support from the family because of a negative view for women who play a dual role (Nahar \& Humaidan, 2013). On the other hand, factors of work environment diversity play an active role in stimulating women to achieve top leadership. Companies that have a concentration of gender diversity programs encourage women to reach higher career paths. Male-dominated companies make it difficult for women to achieve top leadership (Catalyst, 2006).

Companies that have women leaders will have a positive impact on the company's progress (Hora, 2014) as Zhang Shude, Director of China Development Bank, said that women had certain qualities that helped the board function better. He also said that women are more patient, conscientious, and wise in making decisions that increase interaction in the members (Guy et al., 2011; Stawiski et al., 2010). It is this policy that should make the company considers women's integrity in leadership. This study will look at the relationship of women's dependence on leadership with individual characteristics, social support, and with the diversity of work environments. Moreover, there are significant findings regarding the success of women leadership in organizations. Grant and Sandberg (2014) highlighted when more women lead, performance improves. Moreno-Gomez et al. (2017) suggests gender diversity is positively associated with subsequent business performance.

\section{LITERATURE REVIEW}

Watson (2016) has examined leadership excellence and gender through a critical feminist perspective. It is believed there is no difference on leadership excellence base on gender. The enhancement of leadership excellence and the achievement of gender equality in leadership by understanding the systems that disempower women and other oppressed groups and then training men and women to work together to dismantle them (Watson, 2016).

Some experts reveal various notions of individual characteristic constructs. According Zaccaro et al. (2004) and Zaccaro (2007), personal characteristics that foster a consistent pattern of leadership performance across a variety of group and organizational situations. These characteristics reflect a range of stable individual differences, including personality, temperament, motives, cognitive abilities, skills, and expertise. According Hurriyati (2005), individual characteristics is a psychological process that affects individuals in obtaining, consuming and receiving goods and services as well as experience. Individual characteristics are internal (interpersonal) factors that move and influence individual behavior. According to Thoha (2007), individual characteristics are the abilities, personal beliefs and past experiences possessed by an individual and brought into the organizational order. According to Robbins (2013), individual characteristics are personal 
characters such as age, sex, marital status, tenure, educational level and objective marital status and can be easily obtained from personnel records. In this study, individual characteristics are defined operationally as personal characteristics including several dimensions to measure individual characteristics such as the following: Age, marital status, education level, employment, ability, confidence, and past experience (Robbins, 2013; Thoha, 2007).

Social support is a form of giving messages and self-expression so that a person feels himself loved and cared for, respected and valued, and is part of the communication network and mutual obligations of parents, lovers/friends, social networking circles as well as in the community environment (Taylor, 2003). Meanwhile, according to Sarafino (1998), social support is a form of acceptance from a person or group of people towards an individual that raises his perception that he is loved, cared for, valued, and helped. Similar opinion was also raised by Sarrason (2001) who said that social support is the existence, willingness, care of the people around who are reliable, appreciate and love someone. In this study social support is defined operationally as a support to a person so as to feel helped, accepted, valued, and relied upon, derived from the closest people such as family, friends, and people in his or her social environment (Sarafino 1998; Sarrason, 2001; Taylor, 2003). According to Cohen and McKay (1984), Cutrona (1986), Cutrona and Gardner (2004), and Wills and Fegan (2001) dimensions for measuring social support are as follows: emotional support, esteem support, instrumental support, information support, network support.

The diversity of work environments can be defined as individual differences within a unit within an organization that can be measured by the following dimensions: Sex Differences, Age differences, ethnic differences, and religious differences. Women leadership is a capability of a women leader in influencing a group of people to engage in activities to achieve common goals. Here are the indicators to measure women leadership: ability to provide guidance, ability to control, ability to provide briefing.

The relationship of individual characteristics to women leadership can be seen from the results of previous studies. The results of these studies prove that individual characteristics have a relationship with women leadership. This is in line with findings Jepson (2010) and Lahti (2013). According to a survey conducted by Talouselämä magazine to 128 women in top management positions, most have less confident characteristics to be the most influential factor for most women in Finland to move forward (Lahti, 2013). A woman must have the appropriate characteristics to be a leader. On this basis the first hypothesis is stipulated below:

\section{$H_{l}$ : Characteristics Individuals have a relationship with Women Leadership}

The relationship of social support with women leadership can be seen from the results of previous research. The results of previous research indicate social support associated with women leadership. Prior research conducted in Ethiopia by Bullough (2008) and Bullough and de Luque (2015) shows the result of a lack of social support to women causing them to only be in line level work positions or not on top management. Other studies conducted in Jordan also show the same results that women can't freely develop their career without the support of the social environment (Nahar \& Humaidan, 2013). Social support is an important factor for a woman to become a leader (McKinsey\&Company, 2012). On that basis a second hypothesis is set forth below:

$\mathrm{H}_{2}$ : Social Support has a relationship with Women Leadership. 
The relationship between work environment diversity and women leadership can be seen from the results of previous studies. The results of previous studies indicate the diversity of the work environment affecting women leadership. Previous research has been conducted in more than 50 countries that show the result that the diversity of work environment in a company makes a woman get a chance to reach top leadership (McKinsey\&Company, 2008). Another study involving 1735 women professionals also showed similar results, namely the diversity of work environments contributing to women leadership (Catalyst, 2006). Moreno-Gomez et al. (2017) suggests gender diversity is positively associated with subsequent business performance. More concretely, the relationship between gender diversity at the top of the corporate hierarchy - in the present case, as $\mathrm{CEO}$ and in the top management team - and subsequent performance becomes more evident when performance is linked to business operations (ROA), whereas the positive effect of women's representation in the boardroom and subsequent performance is significant when performance is measured via shareholder-oriented metrics (ROE). On that basis, the third hypothesis is stipulated below:

$H_{3}$ : The Diversity of the Work Environment has a relationship with Women Leadership.

The research is done as seen in the research model in Figure 1.

Figure 1: Research Model

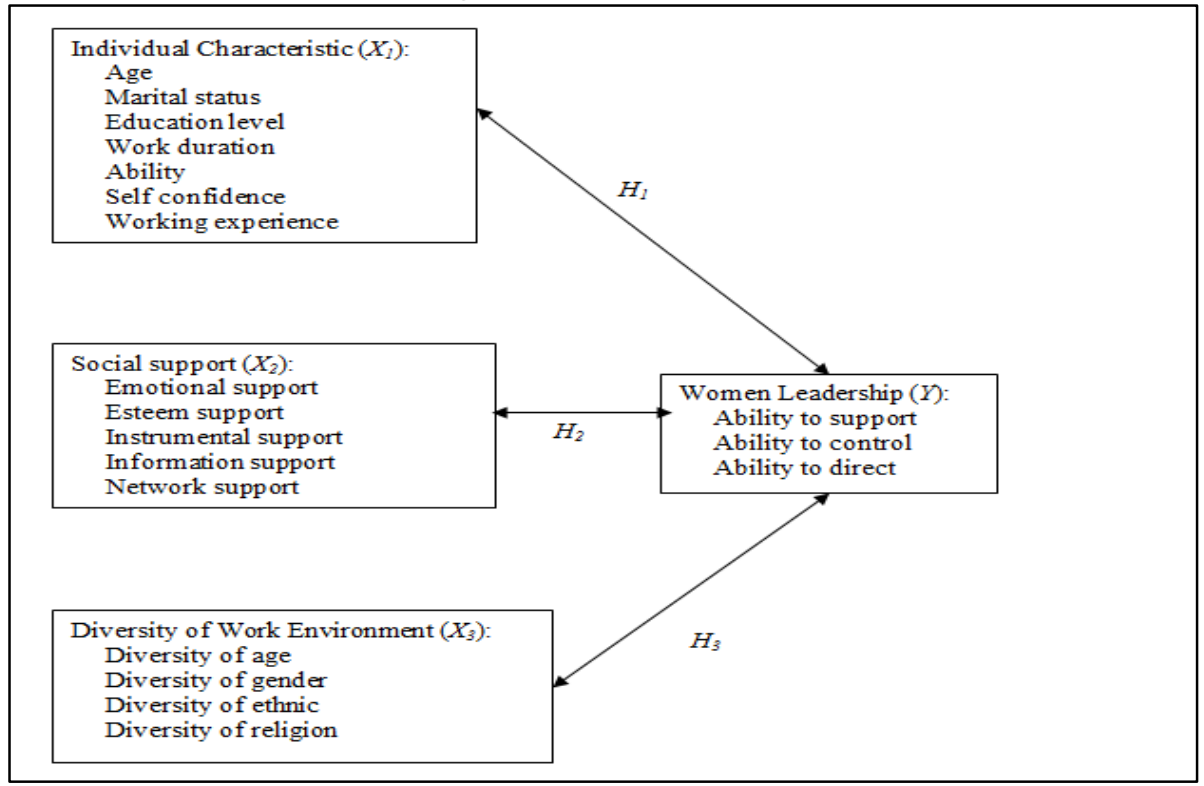

Sources: Cohen and McKay (1984), Cutrona (1986), Cutrona and Gardner (2004), Daft (2007), Robbins (2013), Robbins and Coulter (2012), Schaefer et al. (1981), Thoha (2007; 2010), Wills and Fegan (2001).

\section{METHODOLOGY}


This research uses quantitative research method of associative explanation because it will see the relation of independent variable (Individual Characteristic, Social Support, and Diversity of Work Environment) on dependent variable (Women Leadership). The population of this research is 100 of 134 women leaders in the largest textile manufacturing company in Indonesia which has gone public. Textile industry and product textile is one of the industry's priority to develop a strategic role because in the national economy as the country's foreign exchange contributor, absorb the workforce in large enough quantities, and as the industry relied upon to meet the needs of the national clothing (The Ministry of Industry Indonesia, 2019). They are ranging from supervisor level, head section and manager working on various divisions namely spinning, weaving, finishing and garment, marketing, finance, and design. The sampling technique is purposive sampling with the criterion has occupied a leadership position more than a year.

\section{RESULTS AND DISCUSSION}

After passing and fulfilling the qualification of validity and reliability test, then the dependency test or Chi-Square. Table 1 shows the significance value of Chi-Square test results and the value of Contingency Coefficient to determine whether there is correlation and relationship between variables.

Table 1: Relationship among Variables

\begin{tabular}{|c|c|c|c|}
\hline & \multicolumn{2}{|c|}{ Women Leadership } & \multirow{2}{*}{ Remarks } \\
\hline & Sig. Chi-Square & Contigency Coefficient & \\
\hline \multicolumn{4}{|l|}{ Individual Characteristic: } \\
\hline Age & 0.297 & 0.244 & No relation \\
\hline Marital status & 0.919 & 0.094 & No relation \\
\hline Education level & 0.044 & 0.344 & Low relation \\
\hline Work duration & 0.098 & 0.320 & No relation \\
\hline Ability & 0.002 & 0.411 & Medium relation \\
\hline Self confidence & 0.011 & 0.453 & Medium relation \\
\hline Working experience & 0.001 & 0.395 & Medium relation \\
\hline Social Support & 0.003 & 0.296 & Low relation \\
\hline Diversity of Work Environment & 0.000 & 0.350 & Low relation \\
\hline
\end{tabular}

\subsection{Analysis of Individual Characteristics with Women Leadership}

Based on the results of chi-square test as showed in Table 1, among the seven dimensions of individual characteristics of women leaders, there are three dimensions that are not related to women leadership which are age, marital status and work duration. There is no relationship between age and women leadership. This is shown from the significance value of 0.297 which is greater than 0.05 . There is no relationship between marital status and women leadership. This is shown from the significance value of 0.919 which is greater than 0.05 . Women leadership is not related to their status but with support or not from their husbands. There is no relationship between the period of employment and women leadership. This is indicated by a significance value greater than 0.098 greater than 0.05 .

The three dimensions unrelated to women leadership do not support existing theories and studies that age, marital status and employment relate to women leadership (Primadini, 2012; Thoha, 2007, 
2010). This is because the leadership of women in a company does not focus on age, marital status and work duration. Women whose young age or long-term employment experience still have the opportunity to become a leader if they have the right capabilities for the company. This can be seen from the number of respondents most women leaders are at the age of 25-35 years and at the working period of 5-15 years. The company assumes that young women leaders can also have good leadership because they are more adaptable to changing business environment. Marital status is not related to women leadership. Both married and unmarried women leaders can become leaders as long as have high leadership qualities. Married women leaders are able to produce high leadership because of the support of the closest people such as husband and child, not from their status.

The other four dimensions have a relationship with women leadership, which are education level, ability, self-confidence and working experience. There is a relationship between the education level and women leadership. This is shown from the significance value of 0.044 which is smaller than 0.05. Relation of relationships is relatively weak from the value of contingency coefficient of 0.344 . Based on these results can be concluded that the education level has a relationship with the leadership of women. A woman who has a high education level will be calculated to occupy a position because in accordance with the requirements determined by the company with the consideration that the higher education she has then there is a tendency better knowledge and skills. Other studies have also revealed similar results. The level of education will make a woman in accordance with the quality standards to become a leader in a company (Hora, 2014).

There is a relationship between ability and women leadership. This is shown from the significance value of 0.002 which means smaller than 0.05 . Connection strength is strong enough with the result of contingency coefficient value of 0.411 . Women leaders who have high ability will be able to produce good leadership quality as well. A study involving 7280 women leaders in Norway conducted by Zenger Folkman showed the result that mastering the various abilities of women to be superior to leadership (Patel \& Buiting, 2013).

There is a relationship between self-confidence and women leadership. This is shown from the significance value of 0.011 which means smaller than 0.05 . Connection strength is strong enough with the result of contingency coefficient value of 0.453 . Women who have confidence will increasingly support his ability to become a leader and more daring to take risks faced in leadership. This is in line with the results of biological research that women who have more confidence become a leader because they have the courage to take initiative responsibility as a women leader.

Moreover, there is a relationship between past experiences with women leadership. This is shown from the significance value of 0.001 which means smaller than 0.05 . Connection strength is quite strong with the value of contingency coefficient of 0.395 . Women leaders who previously had leadership experience would be better able to lead their subordinates well. Given the previous experience of being a leader, then a woman has the provision and leadership identity that will be counted by others in the future (Patel \& Buiting, 2013).

Based on the above results it can be said that women leaders who have high individual characteristics can be a women leader in the company of women leaders who have high individual characteristics in terms of ability, confidence and past experience. Such individual characteristics become an essential element for a woman to become a leader. Successful women become leaders 
understand that competent characteristics that lead to effective leadership for enterprise progress (Hayati, 2009).

\subsection{Analysis of Social Support Relationships with Women Leadership}

There is a relationship between social support and women leadership. This is shown from the significance value of 0.003 which means smaller than 0.05 . Relative relationship is relatively weak with the value of contingency coefficient of 0.296 . High social support will help women to improve leadership because they feel comfortable with what they do thanks to the help they get from people in their homes or at work. Women who do not get support from their nearest person such as husbands will usually be at a lower level of leadership because they are used to being dominated and unable to develop their abilities (Le, 2011). Similarly, Sperandio and Kagoda (2009) argues that women in Uganda are successful in leadership because they get support to work not only in feminine work such as administration in social organizations but also in other areas of expertise so that they become more active in achieving leadership.

Women who get emotional support from the people around them such as husbands, children or parents abler to develop leadership because there is no obstacle from the people closest to stay a career. The presence of emotional support from the immediate family creates a feeling of comfort for women to carry on leadership activities in the company. This is because the closest relatives of women leaders such as husbands, children and parents provide support in the form of care, concern and empathy for careers that are run today. In addition, women leaders feel support because their competencies are recognized and respected. This form of support from the company is essential for the advancement of women leadership. This is because the women leaders in the company get a positive appreciation to develop a career to a higher level. Instrumental support is also very meaningful for women leaders to maximize their leadership without worrying about abandoned household tasks such as daycare. This is because household chores and child-rearing tasks for women leaders are no longer an obstacle. These tasks can be replaced by others during business hours. Informational support in the form of suggestions and feedback becomes important to improve and remind women leadership. This suggests that women leaders feel advice, feedback and guidance are helpful to improve their careers. The women leaders get advice from their onepart coworkers or from their supervisor. Women who get guidance and advice will be easier in solving problems faced in the company. In Catalyst (2006), as many as 76 percent of companies with employee development training programs help women to improve their performance so as to rise to a higher level. The same thing was also expressed by Palermo (2004) that women would be easier to get promotion if they get guidance from seniors because it will build social network within the company. In addition, network support is important for women leaders to feel supported in their leadership. This is because women leaders who are often involved in corporate activities will generate a sense of togetherness among colleagues.

The results of this study are in line with the results of previous studies. Prior research conducted in Ethiopia by Bullough (2008) and Bullough and de Luque (2015) shows the result of a lack of social support to women causing them to only be in line level work positions or not on top management. Other studies conducted in Jordan also show the same results that women can't freely develop their career without the support of the social environment (Nahar \& Humaidan, 2013). Social support is an important factor for a woman to be an effective leader (McKinsey\&Company, 2012). The women leader respondents stated that the most meaningful social support came from 
the husband and subsequently from the child. It is also in accordance with what Sarafino and Smith (2011) have said that relationships with non-professionals (family) are relationships that occupy the bulk of a woman's life and become a source of potential social support.

\subsection{Analysis of Workplace Diversity Relationships with Women Leadership}

The diversity of working environments is high. Almost in each division has diverse employee with composition that does not differ much except in the garment division which is preferred women employees to sew. Gender differences become one of the aspects that are quite easy to see the work environment is diverse or not. Employees consist of various age groups, ranging from under 21 years to over 50 years. With employees of these various ages, the work environment becomes more diverse so that women employees of non-senior age groups can get opportunities to develop careers. Employee ethnic differences are also high. Employees are not only from the surrounding environment, but also from other regions and various countries, so that employees have a diverse ethnic. The diversity of religion that is held by employees is high. With such a large number of employees, there are various religions embraced by the employees of Islam, Christianity, Catholicism and Buddhism. Religious differences are an important aspect for the diversity of work environments to provide equal opportunities for everyone without incriminating any one religion. The work environment is quite varied in aspects of gender, age, ethnicity and religion. The diversity that occurs in the work environment will help women leaders to improve their leadership. This is because women do not become a minority in the environment where they work so as to facilitate access and opportunities to grow (Cormier, 2007). Given the diversity it also helps women build a wider social network to get promoted because the relationship is important to get a boost in leadership (Cormier, 2007).

From Table 1 it can be seen that there is a relationship between work environment diversity and women leadership. This is shown from the significance value of 0.000 which means smaller than 0.05 . Relative relationships are relatively weak with the value of contingency coefficient of 0.350 . An increasingly diverse work environment will create a balanced opportunity for women to develop leadership from a wider social network.

The results of this study are in line with the results of previous studies. Previous research has been conducted in more than 50 countries that show the result that the diversity of work environment in a company makes a woman get a chance to reach top leadership (McKinsey\&Company, 2008). Another study involving 1735 women professionals also showed similar results, namely the diversity of work environments contributing to women leadership (Catalyst, 2006). As expressed by Daft (2007) that with the diversity in the working environment of talents of each employee will be able to be used well including the women because of space for women to move more leverage in work. Daft also revealed that a diverse work environment will make leadership in the face of increasing competition because women are also involved to gain a broader scope of talent. From that understanding the diversity of the work environment relates to women leadership.

\section{CONCLUSION}


This study concludes that individual characteristic variables have three dimensions unrelated to women leadership, which are age, marital status and years of service. Four dimensions of individual characteristics relating to women leadership, namely the last education, ability, confidence and past experience. Meanwhile, the variables of social support and work environment diversity have dependency relation on women leadership.

\section{REFERENCES}

Bullough, A. M. (2008). Global Factors Affecting Women's Participation in Leadership (Publication No. 3358429) [Doctoral Dissertation, Florida International University-Miami]. ProQuest Dissertations and Theses Global.

Bullough, A. M., \& de Luque, M. S. (2015). Women's participation in entrepreneurial and political leadership: The importance of culturally endorsed implicit leadership theories. Leadership, 11(1), 36-56.

Bullough, A. M., Kroeck, K. G., Newburry, W., Kundu, S. K., \& Lowe, K. B. (2012). Women's political leadership participation around the world: An institutional analysis. The Leadership Quarterly, 23(3), 398-411.

Catalyst. (2006). Connection That Count: The Informal Networks of Women of Color in the United States. New York, USA: Catalyst.

Cohen, S., \& McKay, G. (1984). Social support, stress and the buffering hypothesis: A theoretical analysis. In A. Baum, J. E. Singer, \& S. E. Taylor (Eds.), Handbook of psychology and health (pp. 253-267). Hillsdale, NJ: Erlbaum.

Cormier, D. (2007). Retaining top women business leaders: Strategies for ending the exodus. Business Strategy Series, 8(4), 262-269.

Cutrona, C. E. (1986). Behavioral manifestations of social support: A microanalytic investigation. Journal of Personality and Social Psychology, 51, 201-208.

Cutrona, C. E., \& Gardner, K. A. (2004). Social support. In A. J. Christensen, R. Martin, \& J. M. Smyth (Eds.), Encyclopedia of health psychology (pp. 280-284). New York: Kluwer.

Daft, R. L. (2007). Management. Jakarta: Salemba Empat.

Grant, A., \& Sandberg, S. (2014, December 6). Women at Work: When Talking about Bias Backfires. The New York Times. https://www.nytimes.com/2014/12/07/opini on/sunday/adamgrant-and-sheryl-sandberg-on-discrimination-at-work.html

Guy, M. L., Niethammer, C., \& Moline, A. (2011). Women on Boards: A Conversation with Male Directors. Washington, D.C.: International Finance Corporation.

Hayati, N. R. (2009). Faktor-faktor yang mempengaruhi kemampuan kaum perempuan dalam kepemimpinan. Paper presented in the Seminar Nasional Wanita, Pusat Studi Wanita, Universitas Gadjah Mada.

Hora, E. A. (2014). Factors that affect women participations in leadership and decision-making position. Asian Journal of Humanity, Art, and Literature, 1(2), 97-117.

Jepson, L. J. (2010). An analysis of factor that influence success of women engineering leaders in corporate America [Doctoral dissertation, Antioch University]. Antioch University Repository \& Archiv. https://aura.antioch.edu/etds/666

Hurriyati, R. (2005), Bauran pemasaran dan loyalitas konsumen. Bandung: ALFABETA.

Lahti, E. (2013). Women and leadership: factor that influence women's career success (Bachelor's tesis, Lathi University of Applied Sciences). https://www.theseus.fi/bitstream/handle/10024/66172/Lahti_Elsi.pdf.pdf 
Le, N. T. T. (2011). How does culture impact on women's leadership in higher education? A case study in Vietnam (Master's thesis, The University of Waikato). https://hdl.handle.net/10289/5313

McKinsey\&Company. (2008). Women matter 2: Female leadership, a competitive edge for the future.

https://www.mckinsey.com/ /media/McKinsey/Business\%20Functions/Organization/Our \%20Insights/Women\%20matter/Women_matter_oct2008_english.pdf

McKinsey\&Company. (2012). Women matter: An asian perspective. https://www.femtech.at/sites/default/files/McKinsey Women.pdf

Moreno-Gomez, J., Lafuente, E., \& Vaillant, Y. (2017). Gender diversity in the board, women's leadership, and business performance. Gender in Management: An International Journal, $33(2), 104-122$.

Nahar, G. S., \& Humaidan, R. L. A. (2013, June). The factor affecting women political participations in Jordanian parliamentary elections (2003-2013). International Journal of Humanities and Social Science, 3(11), 84-94.

Palermo, J. (2004). Breaking the cultural mould: The key to women's career success. Melbourne, Australia: Hudson.

Patel, G., \& Buiting, S. (2013). Gender differences in leadership styles and the impact within corporate board. The Commonwealth Secretariat: Social Transformation Programmes Division.

Primadini, I. (2012). Pengaruh gaya kepemimpinan perempuan dan tingkat kinerja karyawan: Studi pada staf administrasi fakultas ilmu keperawatan Universitas Indonesia (Master's tesis, Universitas Indonesia). Universitas Indonesia Library. http://lib.ui.ac.id/detail?id=20300762

Robbins, S. P. (2013). Organizational behavior. England: Pearson Education Limited.

Robbins, S. P., \& Coulter, M. (2012). Management (1 $11^{\text {th }}$ ed.). New Jearsey: Pearson Education, Inc.

Sarafino, E. P. (1998). Health Psychology: Biopsychosocial Interactions ( $3^{\text {th }}$ ed.). USA: Wiley.

Sarafino, E. P., \& Smith, T. W. (2011). Health psychology: Biopsychosocial interactions. United States of American: John Wiley \& Sonc, Inc.

Sarrason, I. G. (2001). Abnormal psychology. United States of America: Barbara R. Sarason.

Schaefer, C., Coyne, J. C., \& Lazarus, R. S. (1981). The health-related functions of social support. Journal of Behavioral Medicine, 4, 381-406.

Sperandio, J., \& Kagoda, A. (2009). Learning from experience: Improving equality of access and outcomes for girls in Uganda's universal post primary education and raining initiative. In D. S. Baker, \& A. Wiseman (Eds.), Gender, equality, and education from international and comparative perspectives (pp.89-123). International Perspectives on Education and Society Series. St. Louis, MO: Elsevier Science/Emerald Publishing.

Stawiski, S., Deal, J. J., \& Ruderman, M. (2010, April). Building trust in the workplace: A key to retaining women. Center for Creative Leadership. https://cclinnovation.org/wpcontent/uploads/2020/03/building-trust-in-the-workplace.pdf

Taylor, E. S. (2003). Health psychology. United States of America: McGraw-Hill Hinger Education.

The Ministry of Industry Indonesia. (2019). Indutsri tekstil dan produk tekstil direvitalisasi. https://kemenperin.go.id/artikel/60/Industri-Tekstil-Dan-Produk-Tekstil-Di-Revitalisasi

Thoha, M. (2007). Perilaku organisasi konsep dasar dan aplikasinya. Jakarta: PT Raja Grafindo Persada. 
Thoha, M. (2010). Kepemimpinan dan Manajemen. Jakarta: PT Raja Grafindo Persada.

Watson, C. (2016). A critical feminist perspective on leadership excellence and gender. Paper presented at Closing the gender gap: Advancing leadership and organizations. https://doi.org/10.5703/1288284316069

Wills, T. A., \& Fegan, M. F. (2001). Social networks and social support. In A. Baum, T. A. Revenson, \& J. E. Singer (Eds.), Handbook of health psychology (pp. 209-234). Mahwah, NJ: Erlbaum.

Wulandari, N. P. (2015, April 6). Porsi pemimpin wanita di Indonesia menurun. Retrieved May 18, 2018, from http://www.republika.co.id/berita/nasional/umum/15/04/06/nmdrum-porsipemim\%20pin-wanita-di-in\% $1 \mathrm{fdo} \% 1 \mathrm{fnesia-menurun}$

Zaccaro, S. J. (2007). Trait-based perspectives of leadership. American Psychologist, 62(1), 8-16. Zaccaro, S. J., Kemp, C., \& Bader, P. (2004). Leader traits and attributes. In J. Antonakis, A. Cianciolo, \& R. Sternberg (Eds.), The nature of leadership (pp. 101-124). Thousand Oaks, CA: Sage Publications. 